\title{
Pliocene climate and seasonality in North Atlantic shelf seas
}

\author{
By Mark Williams ${ }^{1}$, Alan M. Haywood ${ }^{2}$, Elizabeth M. HarPer ${ }^{3}$, ANDrew L.A.

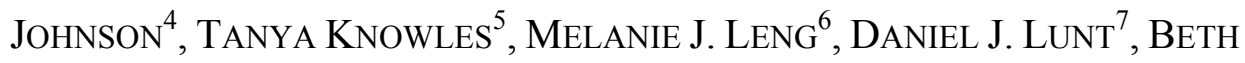 \\ OKAMURA $^{5}$, PAUL D. TAYLOR ${ }^{8}$ AND JAN ZALASIEWICZ ${ }^{1}$ \\ ${ }^{1}$ Department of Geology, University of Leicester, Leicester LE1 7RH, UK \\ ${ }^{2}$ School of Earth \& Environment, University of Leeds, Leeds LS2 9JT, UK \\ ${ }^{3}$ Department of Earth Sciences, University of Cambridge, Cambridge CB2 3EQ, UK \\ ${ }^{4}$ Geographical, Earth \& Environmental Sciences, School of Science, University of Derby, \\ Kedleston Road, Derby DE22 1GB, UK \\ ${ }^{5}$ Department of Zoology, Natural History Museum, Cromwell Road, London SW7 5BD, UK \\ ${ }^{6}$ NERC Isotope Geosciences Laboratory, British Geological Survey, Keyworth, Nottingham, \\ NG12 5GG, UK
}

${ }^{7}$ School of Geographical Sciences, University of Bristol, University Road, Bristol. BS8 1SS, $U K$

${ }^{8}$ Department of Palaeontology, Natural History Museum, Cromwell Road, London SW7 5BD, UK

*Author for correspondence: mri@le.ac.uk

This paper reviews North Atlantic shelf seas palaeoclimate during the interval 4-3 Ma, prior to and incorporating the 'mid Pliocene warm period' (ca 3.29-2.97 Ma). Fossil assemblages and stable isotope data demonstrate northwards extension of subtropical faunas along the coast of the Carolinas-Virginia (Yorktown and Duplin formations) relative to the present day, suggesting a more vigorous Florida Current, with reduced seasonality and warm water extending north of Cape Hatteras (reconstructed annual range for Virginia $12-30^{\circ} \mathrm{C}$ ). This interpretation supports conceptual models of increased meridional heat transport for the Pliocene. Sea temperatures for Florida (Lower Pinecrest Beds) were similar to or slightly cooler (summers $25-27^{\circ} \mathrm{C}$ ) than today, and were probably influenced by seasonal upwelling of cold deep water. Reduced seasonality is also apparent in the Coralline Crag Formation of the southern North Sea, with ostracods suggesting winter sea temperatures of $10^{\circ} \mathrm{C}$ (modern $4^{\circ} \mathrm{C}$ ). However, estimates from Pliocene bivalves (3.6$16.6^{\circ} \mathrm{C}$ ) are similar to or cooler than the present day. This 'mixed' signal is problematic given warmer seas in the Carolinas-Virginia, and climate model and oceanographic data that show warmer seas in the 'mid Pliocene' eastern North 
Atlantic. This may be because the Coralline Crag Formation was deposited prior to peak 'mid Pliocene' warmth.

\section{Keywords: Pliocene; shelf seas; bryozoans; bivalves; seasonality}

Running title: Climate of Pliocene shelf seas

\section{Introduction}

Continental shelf successions of Pliocene age in the North Atlantic are less complete than those of deep marine settings, and they are often bounded by unconformities that resulted from changes in sea level. Consequently, and in contrast to many deep marine sites, they do not provide a temporally complete record of Pliocene ocean conditions. Additionally, shelf successions tend to be preserved during global highstands in sea level (e.g. Dowsett \& Cronin 1990), so that they record warm climate conditions but leave less evidence of cooler conditions. Sea level lowstands, which may have been induced by cooler climates and increased polar ice sheet volumes, are often reflected in unconformities. Local controls on relative sea level may also generate unconformities in shelf successions. Despite these shortcomings, shelf successions can provide an important record of Pliocene sea temperatures, water masses and seasonality through the analysis of a range of fossil organisms, including bryozoans (e.g. O’Dea \& Okamura 2000), bivalves (e.g. Ward et al. 1991; Hickson et al. 1999, 2000; Johnson et al. 2000), gastropods (Jones \& Allmon 1995), ostracods (e.g. Hazel 1971; Wilkinson 1980; Wood et al. 1993; Cronin \& Dowsett 1996), foraminifera (e.g. Jenkins et al. 1988; Dowsett \& Wiggs 1992) and dinoflagellates (e.g. Head 1998; Louwye et al. 2004). In this paper we review evidence for Pliocene palaeoclimates in North Atlantic shelf sea successions deposited between about 4 and 3 million years ago. These records are preserved in three celebrated Pliocene fossilbearing successions (Figs 1, 2): the Coralline Crag Formation of Suffolk, eastern England (e.g. Balson et al. 1993; Gibbard et al. 1998); and the coastal plain sediments of the Carolinas-Virginia (e.g. Ward et al. 1991), and Florida (e.g. Cronin \& Dowsett 1996).

The interval of the Pliocene between 4 and 2.5 million years ago witnessed gradual global cooling and the enhancement of glaciation in the northern hemisphere 
(Zachos et al. 2001). Superimposed on this general cooling trend were intervals of greater warmth, most notably the 'mid Pliocene warm period' (defined as that part of the Mid Pliocene [Piacenzian] between ca 3.29 and 2.97 Ma; see Dowsett \& Poore 1990, Dowsett et al. 1999; Dowsett et al. 2005; Dowsett \& Robinson 2006). Using a large database of oxygen isotope records from benthic and planktonic foraminifera at globally distributed sites, Mudelsee \& Raymo (2005) demonstrated a long-term increase in ice volume from 3.6 to $2.4 \mathrm{Ma}$ (equivalent to a $0.39 \%$ increase in seawater $\left.\delta^{18} \mathrm{O}\right)$. There is an increase in the magnitude of variation in $\delta^{18} \mathrm{O}$, from $0.2 \%$ at 3.2 Ma to $0.3 \%$ at $2.56 \mathrm{Ma}$, which records the increasing amplitude of fluctuation in ice volume, water salinity and/or water temperature, in turn reflecting climate change. The causal factors for global cooling during the late Cenozoic remain unresolved, but may include a combination of tectonic uplift in the Tibetan Plateau and weatheringinduced atmospheric $\mathrm{CO}_{2}$ removal, and the closing of ocean gateways, most notably the Central American Seaway and the Indonesian Seaway. Explanations for the 'midPliocene warm period', which lasted for about 300,000 years, revolve around elevated atmospheric $\mathrm{pCO}_{2}$ levels (e.g. Dowsett et al. 1992; Haywood et al. 2005), increased ocean heat transport from the tropics to higher latitudes (e.g. Dowsett et al. 1992, 1996, 1999), reduced orography (e.g. Haywood et al. 2001), reduced size of the polar terrestrial ice sheets and sea ice cover (Haywood \& Valdes 2004), or combinations of these factors (Dowsett et al. 2005, p. 6; see also Haywood \& Valdes 2004, p. 373).

The mechanism of enhanced meridional ocean heat transport during the "mid Pliocene warm period' would have produced a weaker gradient in North Atlantic sea surface temperatures (SSTs) between the tropics and high latitudes. Thus, high latitude SSTs would be warmer, whilst tropical and low-latitude SSTs would remain the same or cooler. In contrast, elevated concentrations of $\mathrm{pCO}_{2}$ would cause warming at all latitudes (see discussion in Haywood et al. 2005). Organisms whose skeletal chemistry and morphology record a temperature signal throughout the year, including shelf-dwelling bryozoans and bivalves, offer the chance of determining seasonal SST gradients for the North Atlantic and thus provide additional data by which to investigate the forcing mechanism of Pliocene warmth.

The aims of this paper are to: 1) provide a summary correlation scheme for the Pliocene sequences of Florida, Virginia, and the Carolinas in the eastern USA, and Suffolk, eastern England, indicating the formations that record the 'mid Pliocene warm period'; (2) summarise the range of palaeoclimate data from these rock 
successions; (3) recalibrate some of the biogenic oxygen isotope data for palaeotemperature and compare these data with the latest climate model reconstructions for intervals of the Early (Zanclean) and Mid (Piacenzian) Pliocene; and (4) suggest future strategies for maximising the data that can be gleaned from these successions.

Figures 1 and 2 hereabouts

\section{Stratigraphical setting}

The stratigraphical settings of the Pliocene successions in eastern England, VirginiaCarolinas and Florida are summarised in Figure 2. The palaeoenvironmental signal of the Yorktown, Tamiami and Coralline Crag formations has been incorporated into interpretations of 'mid Pliocene' global palaeoclimate (e.g. Dowsett et al. 1994 Table 1, 1996, 1999). However, these formations straddle time intervals that are longer than the ca 300,000 years of the 'mid Pliocene warm period' (equivalent to the Kaena and Mammoth (pars) Subchrons, 3.29 to $2.97 \mathrm{Ma}$; see Dowsett et al. 1999 for definition), often including or entirely comprising successions deposited prior to that interval (Fig. 2). This longer interval records a much greater range of palaeoclimatic variation than is associated with the 'mid Pliocene warm period' alone (e.g. Dowsett \& Poore 1990; Cronin \& Dowsett 1996; Mudelsee \& Raymo 2005). It includes distinctly cooler phases (e.g. isotope stages Gi20 at $4 \mathrm{Ma}$ and M2 at 3.3 Ma sensu Lisiecki \& Raymo 2005).

The Coralline Crag Formation of Suffolk rests unconformably on Eocene deposits of the London Clay Formation and is unconformably overlain by the Red Crag or Norwich Crag formations. Typically 15-20 m thick, the Coralline Crag Formation yields age-diagnostic nannofossils (Jenkins \& Houghton 1987), planktonic foraminifera (Jenkins et al. 1988) and dinoflagellates (Head 1998). Foraminifera, specifically Neogloboquadrina atlantica and Globorotalia puncticulata, suggest correlation with planktonic foraminiferal zones N19 to N21 of Blow (1969; see Jenkins et al. 1988). Dinoflagellates suggest that the sequence straddles the ZancleanPiacenzian boundary. Head (1998, fig. 2), based on a chain of correlation, depicted the youngest Coralline Crag Formation extending to the Mammoth Subchron (C2An2r) and the lower boundary of the formation within Chron C2Ar. Presence of 
the dinoflagellate Operculodinium tegillatum in the Coralline Crag (Head 1997) indicates a maximum age greater than 3.5 Ma (Louwye et al. 2004, p. 363). Dinoflagellates suggest that the lower Ramsholt Member of the formation post-dates the Kattendijk Formation of Belgium and many authors have correlated this unit with the Luchtbal Sands of that country (see Louwye et al. 2004, p. 373), suggesting an age of perhaps $4 \mathrm{Ma}$ or greater (see De Schepper et al. 2004). The minimum age for the formation (at $3.4 \mathrm{Ma}$ ) suggests that it may completely predate the "mid Pliocene warm period'. Much of the biostratigraphical information available for the Coralline Crag Formation comes from the lower part (Ramsholt Member). The upper part (Sudbourne Member) largely comprises tidally generated cross-bedded sandstones in which fossils are winnowed, variably transported and abraded. Importantly, the Ramsholt Member has not suffered the wholesale aragonite dissolution that has afflicted the Sudbourne Member and the laterally equivalent Aldeburgh Member (Balson 1983). This is very significant from the perspective of reconstructing accurate sea temperatures from stable oxygen isotope data preserved in biogenic carbonates in the Coralline Crag Formation.

The Yorktown Formation of the Carolinas-Virginia is unconformity-bound, overlying rocks of the Miocene Eastover Formation and succeeded by the Late Pliocene Chowan River Formation (Ward \& Powars 2004). It comprises four members, representing three transgressive pulses, the middle represented by the Rushmere/Morgart's Beach members. The uppermost Moore House Member is restricted to south-eastern Virginia (Ward et al. 1991). Yorktown Formation stratigraphy and its lateral equivalents are tied with the global planktonic foraminiferal scheme of Berggren (1973; see Dowsett \& Wiggs 1992; also Dowsett \& Cronin 1990), indicating that the succession equates to zones PL1b to PL3 (Fig. 2). Dowsett \& Wiggs (1992) estimated that the Yorktown Formation might represent about one million years of deposition, between about 4 and 3 million years ago, though they favoured an age towards the younger part of that range. Magnetochronology suggests that the upper boundary of the formation in Virginia equates to the Kaena or Mammoth Subchron (Cronin et al. 1994). Ward et al. (1991) considered the Duplin and Raysor formations of the Carolinas to be lateral equivalents of the Rushmere/Morgart's Beach members.

'Unit 11' in the lower Tamiami Formation of Florida is considered of approximate equivalent age to the Sunken Meadow Member of the Yorktown 
Formation (see Cronin \& Dowsett 1996; Allmon et al. 1996, fig. 10.2). The overlying Lower Pinecrest Beds ('units 10-5', see Allmon et al. 1996) represent a major transgression equivalent to the Rushmere/Morgart's Beach/Moore House members of the Yorktown Formation (Cronin \& Dowsett 1996) and to the Duplin and Raysor formations of the Carolinas (see Jones et al. 1991, p. 643). Magnetochronology suggests that at least part of the Lower Pinecrest Beds may have been deposited during the Mammoth or Kaena subchron (Jones et al. 1991; Cronin \& Dowsett 1996). The Upper Pinecrest Beds (units 4-2, see Allmon et al. 1996 and references therein) are separated by a hiatus, and palaeomagnetic data suggest correlation to the Matuyama Chron, and with the Chowan River Formation of south-eastern Virginia and the north-eastern Carolinas (Jones et al. 1991; Dowsett \& Cronin 1996; Fig. 2).

\section{Modern marine-shelf setting adjacent to the selected fossil sites}

The English and North American rock successions preserve a record of Pliocene climate in North Atlantic shelf sea settings across $25^{\circ}$ of latitude in subtropical to temperate climes (modern latitudinal range ca $52^{\circ} \mathrm{N}$ to $27^{\circ} \mathrm{N}$; see Fig. 1) over a time interval that may encompass a million years (Fig. 2). The formations record local acmes of marine conditions during Pliocene times that may therefore correlate with eustatic sea level and regional temperature maxima. It is thus reasonable to assume that the palaeoclimatic signature of fossil organisms will provide a fair comparison with climatic acmes from more open ocean settings at the same latitudes, and this has been supported by comparative studies (see Dowsett \& Wiggs 1992; Cronin \& Dowsett, 1996). Modern North Atlantic Ocean surface-water circulation is dominated by the northward flow of the Gulf Stream, beginning life as the Florida Current flowing northwards from the Florida Straits to Cape Hatteras in North Carolina $\left(35^{\circ} 13^{\prime} \mathrm{N}, 75^{\circ} 32^{\prime} \mathrm{W}\right)$. Beyond Cape Hatteras this warm water current flows away from the continental shelf, becoming the Gulf Stream (Fig. 1).

On the east coast of North America, the sharpest modern faunal boundary occurs at Cape Hatteras (e.g. Roy et al. 1998), defining the junction between subtropical and mild temperate zones. The gradient of temperature change northwards from Cape Hatteras is steep. At Cape Hatteras summer sea temperatures reach ca 26$27^{\circ} \mathrm{C}$ (source http://www.nodc.noaa.gov/dsdt/cwtg/satl.html, November 2007), with winter temperatures averaging about $10^{\circ} \mathrm{C}$ for December-February. A little to the north at Cape Charles in Virginia $\left(37^{\circ} 10.0^{\prime} \mathrm{N}, 75^{\circ} 59.3^{\prime} \mathrm{W}\right)$, summer temperatures are 
similar to Cape Hatteras $\left(25.5^{\circ} \mathrm{C}\right)$ but winter temperatures drop to $4.4^{\circ} \mathrm{C}$ (DecemberFebruary average; data from http://www.nodc.noaa.gov/dsdt/cwtg/satl.html, November 2007). Importantly, Cape Hatteras lies midway between two of the main fossil localities reviewed here, in Virginia and the Carolinas (Fig. 1). Further to the south in the subtropics, winter and summer temperatures off southwest Florida, at depths comparable to those in which the Pinecrest Beds were deposited, are about $16^{\circ} \mathrm{C}$ and $27^{\circ} \mathrm{C}$ respectively (Cronin \& Dowsett 1990, 1996), though surface temperatures are warmer than this (Table 1).

The modern southern North Sea Basin is a shallow (generally less than $40 \mathrm{~m}$ ) and unstratified body of water with little salinity variation (34-35 ppm), though in coastal regions salinity may be somewhat lower as a result of river input. Modern seasonal temperature variations in the southern North Sea range from winter temperatures of $4^{\circ} \mathrm{C}$, to summer temperatures of $17^{\circ} \mathrm{C}$ (see Hickson et al. 1999; Swertz et al. 1999).

\section{Fossil recorders of Pliocene climate on the marine shelf}

Existing palaeoenvironmental data from Pliocene molluscs, ostracods and bryozoans in the North Atlantic region are summarised in Table 1, together with the original absolute temperature values determined from analysis of oxygen isotopes in biogenic carbonates.

Figure 3 and Table 1 about here

\section{Molluscs}

Pliocene deposits of the coastal plain of eastern North America and England contain rich mollusc assemblages (e.g. Krantz 1990; Jones \& Allmon 1995; Harmer 1898; Hickson et al. 1999; Johnson et al. 2000; Ward et al. 1991). In the eastern North Atlantic, the extant Queen Scallop Aequipecten opercularis (Fig. 3a) is a fast-growing bivalve that also occurs in Pleistocene and Pliocene deposits. Today this species inhabits marine settings from low-water to $183 \mathrm{~m}$ depth and has an overall temperature tolerance of $5^{\circ} \mathrm{C}$ (winter minimum) to $24^{\circ} \mathrm{C}$ (summer maximum) (see Johnson et al. 2000). It is tolerant only of small fluctuations in marine salinity, and is not found in sequences deposited under strong fluvial influence. Experimental work 
shows that the calcitic outer part of the shell forms in isotopic equilibrium with seawater, making it a valuable palaeothermometer for ancient sequences (e.g. Hickson et al. 1999, 2000).

On the east coast of the USA well-preserved examples of the gastropods Turritella gladeensis and T. apicalis and the bivalves Mercenaria campechiensis and Carolinapecten eboreus from the Lower Pinecrest Beds of Florida were analysed for stable isotopes by Jones \& Allmon (1995). Krantz (1990) analysed the stable isotopic composition of the extinct pectinid bivalves Chesapecten jeffersonius, C. madisonius and Carolinapecten eboreus from the Yorktown Formation. In both of these studies sea temperatures were estimated from $\delta^{18} \mathrm{O}$ values (see Table 1). Elliot et al. (2003) demonstrated that growth rates in modern Mercenaria from the east coast of North America are reduced or strongly interrupted in waters below $8-10^{\circ} \mathrm{C}$, while there is a summer growth break in warm waters (Quitmyer \& Jones 1987), so that these bivalves may not record the full amplitude of seasonal temperature variation.

\section{Bryozoans}

Cheilostome bryozoans are widespread in Pliocene deposits. These colonial benthic invertebrates have encrusting, erect or free-living colonies that are typically sessile (Fig. 3b). Bryozoans have a global distribution in marine shelf environments. Cheilostome colonies are composed of asexually budded zooids with calcite, aragonite or bimineralic skeletons. Zooid size at the time of budding is determined by ambient water temperature, smaller zooids forming in warmer waters (O'Dea \& Okamura 2000 and references therein). This inverse correlation between zooid size and temperature appears to occur irrespective of food levels, reproductive state, or the overall rate of growth within colonies (e.g. O'Dea \& Okamura 1999). Colonies growing in highly seasonal environments will therefore show a greater variance in zooid size than those in environments experiencing low seasonality. O'Dea \& Okamura (2000) used this relationship to interpret Mean Annual Range of Temperature (MART) experienced by colonies, calibrating the relationship in modern bryozoans (see Table 1).

\section{Microfauna and flora}

Numerous microfossils are present in Pliocene shelf sequences, including ostracods (e.g. Hazel 1971; Wood et al. 1993; Cronin \& Dowsett 1996), foraminifera, (e.g. 
Dowsett \& Wiggs 1992) and dinoflagellates (Head 1998), which have been used for reconstructing water temperature and ocean currents.

\section{Diagnostic predictions of seawater $\delta^{18} \mathrm{O}$ from Early and Mid Pliocene climate model simulations}

In this paper we have recalculated sea temperatures from some of the existing published data for $\delta^{18} \mathrm{O}$ from molluscs (see Table 2). An important consideration in calculating ancient SSTs using the $\delta^{18} \mathrm{O}$ signal is the $\delta^{18} \mathrm{O}$ value of seawater $\left(\delta^{18} \mathrm{O}_{\text {sw }}\right)$. The local or regional $\delta^{18} \mathrm{O}_{\mathrm{sw}}$ is a function of the global mean composition as well as geographical variations caused by the combined effects of changes in evaporationprecipitation patterns, runoff (in coastal regions), and ocean circulation patterns (Zachos et al. 1994; Schmidt 1998). To assess the relative importance of changes on the $\delta^{18} \mathrm{O}_{\mathrm{sw}}$ signal for the Pliocene we utilise diagnostic $\delta^{18} \mathrm{O}_{\mathrm{sw}}$ predictions derived from fully coupled ocean-atmosphere General Circulation Model (OAGCM) simulations, using the UK Meteorological Office Model (HadCM3 GCM), for intervals of the Early and Mid Pliocene. Both of the simulations derive their boundary conditions from the USGS PRISM2 dataset (Dowsett et al. 1999). They incorporate a correction for the reduced polar ice volume of the Pliocene. The only difference between these simulations is that the Central American Seaway (CAS) is specified as open (to a depth of $350 \mathrm{~m}$ ) in the Early Pliocene experiment. Results from these simulations have been published previously in Lunt et al. (2008; Early Pliocene) and Haywood et al. (2007; Mid Pliocene). The response of these models to a closing of the CAS is bipolar with a warming in the Northern Hemisphere and cooling in the Southern Hemisphere. Maximum warming (ca $7^{\circ} \mathrm{C}$ ) in the Northern Hemisphere occurs in the North Atlantic (Fig. 4). However, the change in the global annual mean temperature is small $\left(\mathrm{ca} 0.25^{\circ} \mathrm{C}\right.$ ), which is consistent with the primary response of the system to the closure of the CAS being a reorganization of ocean circulation. There is no large seasonal signal in the response. The bipolar signal persists with a similar magnitude throughout the year (Lunt et al. 2008). The termination, or restriction, of the flow of surface waters through the CAS intensifies North Atlantic thermohaline circulation. This change relates to the cessation (or reduction) of the flow of relatively fresh surface and sub-surface waters from the Pacific into the Atlantic which reduced the buoyancy of North Atlantic surface waters, leading to increased rates of North Atlantic Deep Water (NADW) formation. This increase in NADW formation is 
associated with a strengthened flow of the western boundary currents in the North Atlantic (the Gulf Stream), and an increase in northward heat transport.

Model calculated values for $\delta^{18} \mathrm{O}_{\mathrm{sw}}$ are an attempt to capture longitudinal and latitudinal change as a function of climate, and are based on precipitation minus evaporation ( $\mathrm{P}-\mathrm{E}$ ) estimates derived from the GCM. Present-day observed $\delta^{18} \mathrm{O}_{\mathrm{sw}}$ (Bigg \& Rohling 2000; Schmidt 1998; Schmidt et al. 1999, Global seawater oxygen18 database, available at http://data.giss.nasa.gov/o18data/) is calibrated against observed P - E (ECMWF reanalysis data) for the Atlantic Ocean. The resulting formula (see below) is used to predict $\delta^{18} \mathrm{O}_{\mathrm{sw}}$ gradients for the Pliocene. Atlantic Calibration:

$\delta^{18} \mathrm{O}_{\mathrm{sw}}=0.24-0.008(\mathrm{P}-\mathrm{E}) \quad \mathrm{r}^{2}=0.7$

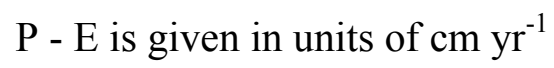

In addition to $\mathrm{P}$ - E we have also calibrated $\delta^{18} \mathrm{O}_{\mathrm{sw}}$ against salinity (Levitus \& Boyer 1994). This increased the $r^{2}$ value to 0.9 but did not significantly change the diagnostic predictions of $\delta^{18} \mathrm{O}_{\text {sw }}$ generated using $\mathrm{P}$ - E. Nevertheless, it is important to recognise that the use of a salinity $\delta^{18} \mathrm{O}$ or $\mathrm{P}-\mathrm{E}: \delta^{18} \mathrm{O}$ co-variation from present-day observations as a diagnostic for the $\delta^{18} \mathrm{O}$ composition of seawater during the Early or Mid Pliocene is complicated by the fact that latitudinal temperature gradients are steeper today than they were during the Pliocene, a reflection of cooler temperatures in polar regions which result in different patterns of Rayleigh distillation and hence different $\delta^{18} \mathrm{O}$ values in the hydrological cycle (Rohling \& Bigg 1998; Rohling 2000).

Table 2 about here

\section{Warm and cool signals in the Pliocene of the southern North Sea}

The Pliocene rocks of eastern England comprise shallow marine silts, sands and shellrich sands deposited on the western margin of the southern North Sea Basin (Fig. 1). This basin may have been open to the north throughout the Pliocene, and was perhaps connected to the North Atlantic via the south during part of the Early and Mid Pliocene (Funnell 1996; Head 1998). However, low planktonic foraminiferal species 
diversity in the Coralline Crag Formation suggests a relatively remote connection with the open ocean waters of the North Atlantic (Jenkins et al. 1988). Water depths may have reached $50 \mathrm{~m}$ or more during deposition of the Ramsholt Member (Hodgson \& Funnell 1987; Head 1998; but see Wilkinson 1980).

Palaeoclimatic analyses of fossils from the Coralline Crag Formation provide conflicting results. Some fossil assemblages attest to warm temperate surface waters, often with Mediterranean characteristics (Harmer 1898; Head 1998). Microfaunal assemblages suggest relatively warm temperatures (e.g. Wood et al. 1993; see Table 1) and reduced seasonality. Jenkins \& Houghton (1987) inferred a maximum range of annual temperature of about $8^{\circ} \mathrm{C}$ based on foraminifera (temperature range $10-18^{\circ} \mathrm{C}$ ), whereas bryozoans suggest overall average temperatures varying between $14^{\circ}$ and $21^{\circ} \mathrm{C}$ (Lagaaij 1963; Cheetham 1967). Higher temperatures than at the present day were also suggested by the smaller zooid sizes found in Coralline Crag populations of several extant bryozoan species compared to living populations (Okamura \& Bishop 1988). O’Dea \& Okamura (2000) applied MART analysis to 11 bryozoan species, arriving at a mean seasonal temperature variation of $6.6^{\circ} \mathrm{C}$, with different species giving values of between 4.6 and $8.9^{\circ} \mathrm{C}$ (see Table 1). In contrast, oxygen isotope values from the mollusc Aequipecten opercularis yielded sea temperature estimates that are similar to today, ranging from a winter value of ca $6.5^{\circ} \mathrm{C}$ to a summer value of $16.6^{\circ} \mathrm{C}$ (see Johnson et al. 2000; herein Tables 1,2). This contrasts with the molluscan faunal analysis of Raffi et al. (1985) which suggested summer temperatures of ' $20^{\circ} \mathrm{C}$ or higher'. However, the Ramsholt Member also yields the bivalve Arctica islandica, which in the modern North Sea has a thermal maximum not exceeding $16^{\circ} \mathrm{C}$ (Witbaard \& Bergman, 2003). Unpublished $\delta^{18} \mathrm{O}$ data from three well-preserved individuals of Arctica islandica from the Ramsholt Member (Harper in preparation, using an ice volume correction for seawater $\delta^{18} \mathrm{O}$ of $-0.35 \%$ ), give a temperature range of $3.6-12.8^{\circ} \mathrm{C}$ which is consistent with the data from Aequipecten.

For estimates of temperature from the shells of Pliocene bivalves in the southern North Sea there is a potential effect of runoff and intense evaporation (opposite effect) in a restricted marine basin. There was freshwater runoff coming into the North Sea from the Baltic, Rhine system and English rivers, but the effect would have been to make the O-isotopic composition of the bivalve shells lighter, giving the appearance of higher temperatures (counter to what is recorded from these shells). 
However, the setting of at least the Ramsholt Member bivalves (offshore in perhaps $50 \mathrm{~m}$ of water depth) makes this effect likely to have been small.

In northern Belgium dinoflagellate cyst assemblages from the Kattendijk Formation, which is probably older than the Ramsholt Member of the Coralline Crag Formation (Louwye et al. 2004), include several thermophilic taxa that suggest warm conditions in the southern North Sea Basin. In contrast, the overlying Luchtbal Sands and lower part of the Oorderen Sands both yield cool water taxa. The Basal Shelly Unit of the Luchtbal Sands may correlate with a pronounced cold stage at about $4 \mathrm{Ma}$ (Marine Isotope Stage Gi16 of Shackleton et al. 1995; renamed Gi20 by Liesecki \& Raymo 2005, fig. 8). These deposits are correlated stratigraphically, in part, with the Coralline Crag Formation. However, Head (1998), while noting that more than $75 \%$ of dinoflagellate taxa from the Coralline Crag Formation are extinct, rendering palaeoenvironmental interpretations based on modern flora uncertain, nonetheless recorded thermophilic taxa. These include persistent Tectatodinium pellitum, which has a modern southern temperate to tropical distribution.

\section{Marine environmental signals from the Pliocene of eastern North America}

The Yorktown Formation of the Carolinas-Virginia comprises sandy clays and shell marls deposited along the Atlantic Coastal Plain. Deposition of the Rushmere/Morgart's Beach members of this formation (Fig. 2) represents the most extensive marine transgression in the Pliocene, creating a shallow shelf sea extending from Maryland to Florida (Ward et al. 1991). This is consistent with the richest foraminiferan assemblages from the middle part of the formation (Dowsett \& Wiggs 1992). To the south, in subtropical Florida, the Tamiami Formation, at least in part, is the lateral equivalent of the Yorktown Formation (Fig. 2). Here, the Lower Pinecrest Beds were deposited during the major transgression onto the shelf that produced the Rushmere/Morgart's Beach members of the Yorktown Formation. There followed a period of marine lowstand, when sea level may have dropped by as much as $50 \mathrm{~m}$ (Cronin \& Dowsett 1996 and references therein), before the Late Pliocene (Gelasian) successions of the Upper Pinecrest Beds and Chowan River Formation were deposited (Fig. 2). 
Ward et al. (1991) summarised the Pliocene-Pleistocene molluscan assemblages from Virginia and the Carolinas and interpreted them in terms of warm and cool coastal water masses. As already noted, Cape Hatteras today defines a major faunal boundary in the marine shelf assemblages of the east coast of the USA. Here the southern limit of the modern Virginian cool temperate mollusc faunal province and the northern limit of the Carolinian subtropical molluscan faunal province effectively meet (Ward et al. 1991). These provinces are defined by the southwards-flowing cool water Virginia Current, and the northwards-flowing warm water Carolina Coastal Current and Florida Current, the latter being deflected towards the ocean at Cape Hatteras as the Gulf Stream. The result of convergence of these warm and cold water currents is that the warm temperate regime is eliminated, and the temperate molluscan fauna is greatly reduced (Ward et al. 1991).

The faunal provinces of the Pliocene on the east coast were clearly very different for part of this epoch. During the Early Pliocene (Yorktown Formation, Sunken Meadow Member), a cool temperate molluscan fauna in water depths of perhaps $20 \mathrm{~m}$ extended from Virginia to the Carolinas (Ward et al. 1991, fig. 16-4). The marine transgression which deposited the Rushmere/Morgarts Beach members of the Yorktown Formation introduced a warm subtropical molluscan fauna to South Carolina, with warm temperate faunas extending from North Carolina to Virginia (Ward et al. 1991, fig. 16-4). Much of the Florida Peninsula would have been submerged at this time (equivalent to the time of deposition of Tamiami Formation units 5 to 10), and Ward et al. (1991) speculated that the Gulf Stream was deflected westwards. Finally, the Moore House Member of the Yorktown Formation introduced a warm temperate to subtropical marine molluscan assemblage into Virginia. These patterns of mollusc distribution indicate that for much of the Mid Pliocene (Rushmere to Moore House members; see Fig. 2) warmer waters than at present extended north of Cape Hatteras (see Table 1).

The warm water interpretation of the molluscan fauna is supported by evidence from microfauna. Cronin \& Dowsett (1990) identified a warm water tropical ostracod fauna in the Duplin Formation of North Carolina, suggesting bottom water temperatures as warm as $18^{\circ} \mathrm{C}$ for winter and $26^{\circ} \mathrm{C}$ for summer. Dowsett \& Wiggs (1992) used foraminifer assemblages in the Yorktown Formation, especially the common occurrence of Globigerinoides sacculifer, in post-Sunken Meadow Member 
strata, to indicate winter temperatures $3-5^{\circ} \mathrm{C}$ warmer but summer temperatures similar to the present day.

Analysis of oxygen isotopes in the bivalves Carolinapecten and Chesapecten from the Yorktown Formation (Krantz 1990) supports the notion of more equable conditions extending north of Cape Hatteras in the Early and Mid Pliocene (Table 1). These data suggest reduced seasonality with winter temperatures $\left(\mathrm{ca} 8.6^{\circ} \mathrm{C}\right.$ ) warmer than those experienced in the coastal waters of modern Virginia (see Table 1), but with summer temperatures cooler (ca $24^{\circ} \mathrm{C}$ ). Krantz (1990) used ice volume correction factors between -0.3 and $-0.6 \%$ for seawater $\delta^{18} \mathrm{O}$ to calculate palaeotemperatures (based on polar ice sheets with a reduced volume). We have recalculated palaeotemperatures for this material (Table 2) using seawater isotope values generated by GCMs specifically for this region, one for the Early Pliocene $\left(\delta^{18} \mathrm{O}=0.7 \%\right.$ ) and another for the Mid Pliocene $\left(\delta^{18} \mathrm{O}=1.1 \%\right.$ ) (see Fig. 4). In both instances our correction factors result in warmer winter temperatures (ca $12-14^{\circ} \mathrm{C}$, see Table 2) and summer temperatures that are similar to present day summer coastal temperatures in Virginia.

\section{Subtropical Florida}

Jones \& Allmon (1995, fig. 12) summarised a range of palaeotemperature data for the Pinecrest Beds, comparing these with modern sea temperatures off Florida in water depths from 2 to $35 \mathrm{~m}$. They noted (op. cit., p. 69) that evidence from ostracods (see also below) suggested water temperatures during Pinecrest Beds deposition to be as much as $2.4^{\circ} \mathrm{C}$ cooler in August and $0.6^{\circ} \mathrm{C}$ cooler in February. Studies of pollen, foraminifera and ostracods (Willard et al. 1993) have supported the interpretation of cooler summer temperatures. To calculate palaeotemperatures from bivalves and gastropods Jones \& Allmon (1995) used a range of different estimates of local seawater $\delta^{18} \mathrm{O}$, including correction factors for the difference between modern and Pliocene ice volume. Values of sea temperature determined from the isotopic composition of the aragonitic bivalve Mercenaria campechiensis from the middle of the main shell bed in unit 6/7 (Lower Pinecrest Beds), where fully marine conditions pertained, suggest seasonal extremes of temperature of $10.9^{\circ} \mathrm{C}$ and $24.3^{\circ} \mathrm{C}$, whilst values from the gastropod Turritella suggest $13^{\circ} \mathrm{C}$ to $25.7^{\circ} \mathrm{C}$. Jones \& Allmon (1995, p. 70) favoured palaeotemperatures based on seawater $\delta^{18} \mathrm{O}$ values uncorrected for reduced ice volume, as these provided temperatures $\left(14.2\right.$ to $24.3^{\circ} \mathrm{C}$ for Mercenaria 
and 16.4 to $25.7^{\circ} \mathrm{C}$ for Turritella; see Table 1) more consistent with interpretations from ostracods and foraminifera (Willard et al. 1993). Jones \& Allmon (1995, p. 70) noted in general that the isotopic values of molluscs in unit $6 / 7$ were cold-shifted relative to modern temperatures (see also Table 1); those from the younger unit 2 were more similar to the present day (non ice-corrected values for Turritella were $16.4-25.7^{\circ} \mathrm{C}$ ). Our recalculations from two of their Mercenaria bivalve shells (MC130 and $\mathrm{MC} 121$ ) suggest palaeotemperatures in the range 16 to $27^{\circ} \mathrm{C}$ that are very similar to modern values in this region (Table 2).

Analysis of ostracod faunas through the interval of the Tamiami Formation to Pleistocene Bermont Formation by Cronin \& Dowsett (1996, following on from Cronin \& Dowsett 1990) led these authors to infer warmer winters and cooler summers, and a narrower range of seasonal temperature variation compared to today for much of the Pliocene. Although they noted that some of the ostracod faunas had no modern analogues (for example in 'Unit 11'), Cronin and Dowsett were able to suggest cool temperatures for the Early Pliocene (winter temperatures less than $17^{\circ} \mathrm{C}$, summer temperatures about $22^{\circ} \mathrm{C}$ ). During deposition of the Lower Pinecrest Beds (units 5 to 10), they interpreted summer temperatures to be typically 21 to $27^{\circ} \mathrm{C}$ (total range, but ranges vary from horizon to horizon, op. cit. fig. 4.7, table 4.2), and winter temperatures that were typically 18 to $21^{\circ} \mathrm{C}$. The dominance of brackish water faunas in the Upper Pinecrest Beds rendered interpretations of water temperature difficult, but Cronin and Dowsett inferred winter and summer temperatures between 17 and $24^{\circ} \mathrm{C}$ (total range) for the uppermost part of this interval. In general, Pliocene temperatures in Florida appear to have been characterised by slightly cooler summers than at the present day (see Tables 1, 2).

Figure 4 hereabouts

\section{Comparison with Pliocene climate models and data from the open oceans}

Analysis of sea temperature data gleaned from planktonic foraminifera over longer time intervals for the Pliocene indicates climatic variability with periodicities associated with secular variations in the Earth's orbit, particularly the 41 kyr obliquity cycle (e.g. Dowsett \& Poore 1990). Such detailed interpretation depends on high 
resolution data from ocean sites, with sampling of foraminifera at intervals of sediment representing ca $10 \mathrm{kyr}$ intervals, and with excellent stratigraphical control (Dowsett \& Poore 1990; Dowsett \& Robinson 2006). Superimposed on this high frequency variability are longer term changes in mean temperature values which delineate distinct intervals when climate was warmer or cooler than today. Thus, Dowsett \& Poore (1990, p. 191) identified: (1) an interval in the earlier Pliocene when SSTs were generally cooler than today; (2) an interval centred around 3.3-3 Ma when temperatures were warmer; and (3) decreasing SSTs thereafter.

Subsequent analysis of a large palaeontological dataset by the Pliocene Research, Interpretation and Synoptic Mapping (PRISM) Group of the USGS indicated that SSTs at mid and high latitudes were warmer than at the present day, defining the 'mid-Pliocene warm period' (Dowsett et al. 1994, 1999). Within this interval SSTs were under the influence of 'background' high frequency orbital effects on climate, but were, on the whole, warmer than present. Dowsett et al. (1992) noted that faunal data for the North Atlantic indicated SSTs warmer at mid to high latitudes but a little cooler at low latitudes, a signal they interpreted as a response to increased meridional heat transfer from low to high latitude. This pattern of warming at midand high latitudes with cooling or unchanged SSTs in low latitudes is also manifested in global reconstructions of the Pliocene based on faunal analysis techniques (e.g. Dowsett et al. 1999). However, subsequent analysis of palaeoclimatic data from tropical and mid latitude upwelling regions has suggested warming during the "mid Pliocene' (e.g. Dowsett \& Robinson this volume; Dekens et al. 2007; Haywood et al. 2005). Furthermore, model outputs using coupled ocean-atmosphere models for the mid-Pliocene (Haywood \& Valdes 2004; Haywood et al. 2005) indicate a small degree of warming (relative to the pre-industrial era) in general in the tropics, with the largest degree of warming still centred on the high-latitudes. Climate model experiments using a coupled ocean-atmosphere GCM conducted by Haywood and Valdes (2004) have shown that high latitude warming during the 'mid Pliocene' may have been strongly influenced by changes in albedo as a result of reduced polar ice sheets, rather than increased meridional heat transfer.

A pattern of slight tropical warming coupled with more dramatic warming at higher latitudes is one that might be anticipated if warming was at least partly a function of increased $\mathrm{CO}_{2}$ in the atmosphere. The reconciliation of data versus model outputs for the Pliocene tropics must be a major focus for future study, although the 
difficulties therein are acknowledged with respect to the ability of proxy records to robustly detect SST changes of very small magnitude (i.e. an unfavourable signal to uncertainty ratio) and that in areas such as the western equatorial Pacific suitable calibrations for faunal analysis and alkenone palaeothermometry are not available.

At present, data from fossil organisms occupying the Pliocene shelf seas of the North Atlantic do not resolve the forcing mechanisms of the 'mid Pliocene warm period' and in some instances they provide palaeoclimatic data that is inconsistent with that from oceanic sites. This may be because, in part, they represent older time intervals than the 'warm period' (Fig. 2). Thus, the faunas of 'Unit 11' in the Tamiami Formation of Florida and its lateral equivalent the Sunken Meadow Member of the Yorktown Formation, which definitely antedate the 'mid Pliocene warm period' (Fig. 2), preserve a signal of a slightly cooler (though not cold) Pliocene interval (e.g. Krantz 1990; Cronin \& Dowsett 1996; see also Table 1). Later deposits (Yorktown and Duplin formations), which incorporate the 'mid Pliocene warm period', provide evidence for a more vigorous transfer of heat from the tropics along the east coast of North America such that warm water penetrated along the coast of Virginia north of Cape Hatteras. This interpretation would support the hypothesis of increased meridional heat transport. This ensured warmer winters throughout much of Yorktown Formation times (see Dowsett \& Wiggs 1992, p. 82; herein Table 2), and is consistent with climate model reconstructions for the Early and Mid Pliocene (cf. Table 2 data and Fig. 4).

Cooler summer temperatures off Florida during deposition of the Lower Pinecrest Beds may have been the result of seasonal upwelling of deep water (see Jones \& Allmon 1995). This is suggested in the carbon isotope profiles of some shells of the bivalve Mercenaria from unit 6/7 of the Lower Pinecrest Beds, which show light carbon values (from deep waters enriched in ${ }^{12} \mathrm{C}$ ) corresponding to heavy oxygen values (indicating cool water; Jones \& Allmon 1995, fig. 9b).

Conditions in the southern North Sea during the Early and Mid Pliocene are more equivocal. Most of the Coralline Crag Formation seems to have been deposited prior to $3.4 \mathrm{Ma}$; that is, before peak 'mid Pliocene' warming (Fig. 2). This, in itself, appears to be inconsistent with the model of maximum sea level achieved during the warm period (e.g. Dowsett \& Cronin 1990). The explanation may lie in: (1) significant local control on relative sea level (see Mathers \& Zalasiewicz 1988); (2) a problem of stratigraphical correlation; (3) sea level change associated with a cold 
glacial stage (e.g. M2 which occurred at about 3.4 Ma around the time that sedimentation of the Coralline Crag may have ceased in the North Sea, see Fig. 2); or (4) a combination of these factors.

As noted, signals from different fossil groups in the Coralline Crag Formation provide contrasting records of climate. Wilkinson (1980) summarised fossil evidence from earlier workers, pointing out that the presence of the free-living bryozoan Cupuladria, for example, suggested that winter temperatures did not fall below $14^{\circ} \mathrm{C}$ (Lagaaij 1963). A warmer North Sea during deposition of the Coralline Crag Formation is also consistent with an enhanced Gulf Stream effect. Indeed, 'mid Pliocene' SSTs recorded at NE Atlantic Deep Sea Drilling Project sites 548 and 552 (see Fig. 1) are significantly warmer than present (Dowsett \& Poore 1991, fig. 2; Dowsett et al. 1992, fig. 2), by some $5^{\circ} \mathrm{C}$ in winter months (op cit., fig. 1). However, there are also indications of Coralline Crag Formation temperatures being similar to or even cooler than the present day (e.g. data from the bivalve Aequipecten, see Tables 1, 2; and Harper unpublished data). Johnson et al. (2000, p. 429) speculated that cool temperature signals from two Coralline Crag Formation valves of $A$. opercularis (see Tables 1, 2) might represent anomalously cold years, or cryptic diagenesis. Their evidence from growth increment analysis of these fossils (with substantially wider increments interpreted as representing warmer summers than present), favoured the latter explanation.

Climate was clearly not static through the period prior to $3 \mathrm{Ma}$, as evidenced from oxygen isotope records in foraminifera (Dowsett \& Poore 1990; Mudelsee \& Raymo 2005; Lisiecki \& Raymo 2005), and as also displayed in varied palaeoclimate data obtained through detailed sampling of the Pliocene sequence of Florida (e.g. see Cronin \& Dowsett 1996, table 4.2). There are a number of possible explanations for the mixed signals in the Coralline Crag Formation. These include: (1) reworking of shells from time intervals when climate was different (cooler?) from those at the time the sediment was deposited; (2) the discontinuous nature of the rock record, which may preserve different palaeoclimatic regimes at different places; (3) sampling at low stratigraphical resolution, with material being imprecisely located in rock successions recording more than one climatic state (as suggested by stratigraphic variation in facies: see Balson et al. 1993); and (4) diagenesis in meteoric waters resetting geochemical signals, as noted by Johnson et al. (2000). There is currently no detailed study of diagenetic alteration in bivalve material from the Coralline Crag Formation 
although in the context of cement precipitation from meteoric waters (Balson 1983) it is difficult to conceive how shell material could have become ${ }^{18} \mathrm{O}$-enriched, thus yielding cool isotopic temperatures

The Coralline Crag Formation represents sediments deposited above storm wave base in which material was transported and reworked. Wilkinson (1980) estimated depths as little as $20 \mathrm{~m}$ for deposition and noted that for the microfauna contamination and intermixing of assemblages were major problems for interpretation. The hypothesis of wholesale reworking of larger shells, such as those of terebratulid brachiopods or the bivalve Arctica, has not been investigated in detail though Balson et al. (1993, p. 69) suggested widespread reworking of shells in the Sudbourne Member (Fig. 2). However, more recent evaluations of Arctica specimens from the Ramsholt Member suggest that in this unit they are well-preserved and have not been subject to reworking (Harper, recent observations). At many localities (e.g. Broom Pit) a particular fossil organism, such as Arctica, is seen to be dominant at a particular horizon. The significance of this in terms of environmental change remains to be determined. The complex lithostratigraphy of the Coralline Crag deposits, with intraformational unconformities (Balson et al. 1993, p. 63), lends support to the idea that stratigraphically un-localised material could encompass different climate regimes, especially if the whole formation represents a time period of greater than 200,000 years (e.g. see stratigraphy of Wood et al. 1993, fig. 3), during which high frequency climatic change may well have occurred (Lisiecki \& Raymo 2005; Dowsett et al. 2005).

Although data from the Coralline Crag Formation are sometimes inconsistent with the model of warming in the North Atlantic presented by Dowsett et al. (1992, 1996, 1999) for the 'mid Pliocene', interpretations of cooler sea temperatures from bivalve data in the Coralline Crag Formation are consistent with climate models for the Early Pliocene that display little or no warming for the North Sea (see Fig. 4a). They are also consistent with the high variability of NE Atlantic climate identified by Dowsett et al. (2005, fig. 6; see also Draut et al. 2003) in which SSTs may vary by more than $2^{\circ} \mathrm{C}$ over geologically short intervals of 5000 years.

\section{Conclusions}

A review of existing data for Pliocene sequences in Suffolk, eastern England and along the east coast of North America demonstrates their partial correlation, and in all 
instances shows that they record time intervals which in part precede peak warmth of the 'mid Pliocene warm period'. Analysis of bryozoan, bivalve and microfossils in these deposits shows a northwards shift of subtropical faunas along the coast of the Carolinas-Virginia relative to present day, with reduced seasonality and warm water extending northwards beyond Cape Hatteras: during deposition of the Yorktown Formation winter temperatures were much warmer than at the present day. This observation would support conceptual models of increased meridional heat transport for the Pliocene. Reduced seasonality is also apparent in the southern North Sea, with estimates from ostracods suggesting winter temperatures warmer than $10^{\circ} \mathrm{C}$, but estimates from bivalves (Aequipecten seasonal range ca $6.5-16.6^{\circ} \mathrm{C}$ ) giving values similar to the present day. This mixed signal is a paradox and might be a function of material representative of different (cool and warm) climatic states being mixed.

This review reveals the need for a detailed stratigraphical analysis and sampling of the Coralline Crag Formation, in the manner of that undertaken for the Pinecrest Beds of Florida (e.g. Jones \& Allmon 1996; Cronin \& Dowsett 1996). In particular, environmental, taphonomic and diagenetic data from bryozoans (MART analysis), ostracods, dinoflagellates, bivalves and brachiopods need to be integrated horizon by horizon. There is also a dearth of oxygen isotope data from bivalves in the Yorktown Formation, and no published detailed data from the Duplin and Raysor formations of the Carolinas, though both areas bear similar mollusc assemblages (Ward et al. 1991). Ongoing work on Chesapecten from Florida to Delaware will provide a more complete picture of palaeoclimate along the eastern seaboard of North America during the Mid Pliocene (Goewert \& Surge 2007). These deposits also contain extensive cheilostome bryozoans, and these hold great potential for future MART analysis of Pliocene sequences (Knowles et al. 2006).

We are very grateful for the constructive comments of the two reviewers which have greatly improved this work, and to Paul Valdes who edited this paper. We also thank Peter Long (Leicester), Harry Dowsett (USGS), Lauck Ward (Virginia) and Roger Portell (Florida) for discussions on Pliocene stratigraphy and molluscs. Mark Williams thanks Leicester University for study leave.

\section{References}

Allmon, W.D., Rosenberg, G., Portell, R.W. \& Schindler, K. 1996. Diversity of Pliocene-Recent mollusks in the western Atlantic: extinction, origination, and 
environmental change. In Evolution and environment in tropical America (eds B.C. Jackson, A.F. Budd \& A.G. Coates), pp. 217-302. University of Chicago Press.

Balson, P.S. 1983. Temperate meteoric diagenesis of Pliocene skeletal carbonates from eastern England. Journal of the Geological Society 140, 377-385.

Balson, P.S., Mathers, S.J. \& Zalasiewicz, J.A. 1993. The lithostratigraphy of the Coralline Crag (Pliocene) of Suffolk. Proceedings of the Geologists' Association 104, 59-70.

Berggren, W.A. 1973. The Pliocene timescale: calibration of planktonic foraminiferal and calcareous nannofossil zones. Nature 243, 391-397.

Bigg, G. R. \& Rohling, E.J. 2000. An oxygen isotope data set for marine waters, Journal of Geophysical Research 105, 8527- 8535.

Blow, W.H. 1969. Late middle Eocene to Recent planktonic foraminiferal biostratigraphy. In Proceedings of the First International Conference on Planktonic Microfossils (eds P. Bronniman \& H.H. Renz), pp. 199-422. Leiden: E.J. Brill.

Carré, M., Bentaleb, I., Blamart, D., Ogle, N., Cardenas, F., Zevallos, S., Kalin, R.M., Ortlieb, L. \& Fontugne, M. 2005. Stable isotopes and slecrochronology of the bivalve Mesodema donacium: potential application to Peruvian paleoceanographic reconstructions. Palaeogeography, Palaeoclimatology, Palaeoecology 228, 4-25.

Cheetham, A.H. 1967. Paleoclimatic significance of the bryozoan Metrarabdotos. Transactions of the Gulf Coast Association of Geological Societies 17, 400-407.

Cronin, T.M. \& Dowsett, H.J. 1990. A quantitative method for shallow marine paleoclimatology: applications to Pliocene deposits of the western North Atlantic Ocean. Marine Micropalaeontology 16, 117-148.

Cronin, T.M. \& Dowsett, H.J. 1996. Biotic and oceanographic response to the Pliocene closing of the Central American Isthmus. In Evolution and environment in tropical America (eds J.B.C. Jackson, A.F. Budd \& A.G. Coates). pp. 76-104. University of Chicago Press.

Cronin, T.M., Willard, D.A., Dowsett, H.J., Ishman, S.E. \& Holtz, T.R. Jr. 1994. The Yorktown Formation of Virginia: implications for late Pliocene climate and sea level history. Geological Society of America Abstracts with Programs 25(6), A334. 
Dekens, P. S., Ravelo, A.C. and McCarthy, M.D. 2007 Warm upwelling regions in the Pliocene warm period. Paleoceanography 22, PA3211. (doi:10.1029/2006PA001394).

De Schepper, S., Head, M.J. \& Louwye, S. 2004. New dinoflagellate cyst and incertae sedis taxa from the Pliocene of northern Belgium, southern North Sea Basin. Journal of Paleontology 78, 625-644.

Dowsett, H.J. \& Cronin, T. 1990. High eustatic sea level during the middle Pliocene: evidence from the southeastern U.S. Atlantic coastal plain. Geology 18, 435-438.

Dowsett, H.J. \& Poore, R.Z. 1990. Pliocene sea surface temperatures of the North Atlantic Ocean at 3.0 Ma. Quaternary Science Reviews 10, 189-204.

Dowsett, H.J. \& Wiggs, L.B. 1992. Planktonic foraminiferal assemblage of the Yorktown Formation, Virginia, USA. Micropaleontology 38, 75-86.

Dowsett, H.J. \& Robinson, M.M. 2006. Stratigraphic framework for Pliocene paleoclimate reconstruction: the correlation conundrum. Stratigraphy 3, 53-64.

Dowsett, H.J. and Robinson, M.M. this volume. Mid-Pliocene equatorial Pacific sea surface temperature reconstruction: A multi-proxy perspective. Philosophical Transactions of the Royal Society of London A.

Dowsett, H.J., Barron, J., Poore, R.Z. 1996. Middle Pliocene sea surface temperatures: a global reconstruction. Marine Micropalaeontology 27, 13-25.

Dowsett, H.J., Chandler, M.A., Cronin, T.M. \& Dwyer, G.S. 2005. Middle Pliocene sea surface temperature variability. Paleoceanography 20, PA2014, doi:10.1029/2005PA001133.

Dowsett, H.J., Cronin, T., Poore, R.Z., Thompson, R.S., Whatley, R.C. \& Wood, A.M. 1992. Micropaleontological evidence for increased meriodional heat transport in the North Atlantic Ocean during the Pliocene. Science 258, 1133-1135.

Dowsett, H.J., Thompson, R., Barron, J., Cronin, T., Fleming, F., Ishman, S., Poore, R.Z., Willard, D. \& Holtz, J. Jr. 1994. Joint investigations of the Middle Pliocene climate I: PRISM paleoenvironmental reconstructions. Global and Planetary Change 9, 169-195. 
Dowsett, H.J., Barron, J.A., Poore, R.Z., Thompson, R.S., Cronin, T.M., Ishman, S.E. \& Willard, D.A. 1999. Middle Pliocene Paleoenvironmental Reconstruction: PRISM2. US Geological Survey Open File Report 99-535. http://pubs.usgs.gov/openfile/of99-535.

Draut, A.E., Raymo, M.E., McManus, J.F. \& Oppo, D.W. 2003. Climate stability during the Pliocene warm period. Paleoceanography 18 (4), 1078, doi:10.1029/2003PA000889.

Elliot, M., deMenocal, P.B., Linsley, B.K. \& Howe, S.S. 2003. Environmental controls on the stable isotopic composition of Mercenaria mercenaria: Potential application to paleoenvironmental studies, Geochemistry Geophysics Geosystems 4 (7), 1056, doi:10.1029/2002GC000425.

Funnell, B.M. 1996. Plio-Pleistocene palaeogeography of the southern North Sea Basin (3.75-0.60 Ma). Quaternary Science Reviews 15, 391-405.

Gradstein, F.M., Ogg, J.O. \& Smith, A.G. 2004. A geologic time scale 2004. Cambridge University Press.

Gibbard, P.L., Zalasiewicz, J.A. \& Mathers, S.J. 1998. Stratigraphy of the marine Plio-Pleistocene crag deposits of East Anglia. Medelingen Netherlands Instituut voor Toegepaste Geowetenschappen TNO 60, 239-262.

Grossman, E.L. \& Ku, T.-L. 1986. Oxygen and carbon isotope fractionation in biogenic aragonite: temperature effects. Chemical Geology 59, 59-74.

Goewert, A.E. \& Surge, D. 2007. Seasonal variations preserved in an extinct Neogene scallop, Chesapecten, from Florida to Delaware, USA and its implications for paleobiogeography. Eos Transactions AGU 88 (52), Fall Meeting Supplement, Abstract PP51E-05.

Harmer, F.W. 1898. The Pliocene deposits of the East of England: The Lenham Beds and the Coralline Crag. Quarterly Journal of the Geological Society 54, 308356.

Haywood, A.M. \& Valdes, P.J. 2004. Modelling Pliocene warmth: contribution of atmosphere, oceans and cryosphere. Earth and Planetary Science Letters $\mathbf{2 1 8}$, 363-377. 
Haywood, A.M., Valdes, P.J. \& Peck, V.L. 2007. Permanent El Niño-like conditions during the Pliocene? Paleoceanography 22, doi:10.1029/2006PA001323.

Haywood, A.M., Dekens, P., Ravelo, A.C. \& Williams, M. 2005. Warmer tropics during the mid-Pliocene? Evidence from alkenone paleothermometry and a fully coupled ocean-atmosphere GCM. Geochemistry, Geophysics, Geosystems 6, 120.

Haywood, A.M., Valdes, P.J., Sellwood, B.W., Kaplan, J.O. \& Dowsett, H.J. 2001. Modelling Middle Pliocene Warm Climates of the USA. Palaeontologia

Electronica 4, issue 1, art. 5, 21 pp. http://palaeoelectronica.org/2001_1/climate/issue1_01.htm.

Hazel, J.E. 1971. Paleoclimatology of the Yorktown Formation (upper Miocene and lower Pliocene) of Virginia and North Carolinas. Centre Recherches Pau-SNPA Bulletin 5, 361-375.

Head, M.J. 1997. Thermophilic dinoflagellate assemblages from the mid Pliocene of eastern England. Journal of Paleontology 72, 165-193.

Head, M.J., 1998. Marine environmental change in the Pliocene and early Pleistocene of eastern England: the dinoflagellate evidence reviewed. In T. Van Kolfschoten \& P.L. Gibbard (eds), The Dawn of the Quaternary. Mededelingen Nederlands Instituut voor Toegepaste Geowetenschappen TNO 60, 199-225.

Hickson, J.A., Johnson, A.L.A., Heaton, T.H.E. \& Balson, P.S. 1999. The shell of the Queen Scallop Aequipecten opercularis (L.) as a promising tool for palaeoenvironmental reconstruction: evidence and reasons for equilibrium stableisotope incorporation. Palaeogeography, Palaeoclimatology, Palaeoecology 154, $325-337$.

Hickson, J.A., Johnson, A.L.A., Heaton, T.H.E. \& Balson, P.S. 2000. Late Holocene environment of the southern North Sea from the stable isotopic composition of Queen Scallop shells. Palaeontologia Electronica 3, 11 pp.

Hodgson, G.E. \& Funnell, B.M. 1987. Foraminiferal biofacies of the early Pliocene Coralline Crag. Micropalaeontology of carbonate environments (ed M.B. Hart). pp. 44-73. BMS Special Publication. Chichester: Ellis Horwood Ltd. 
Jenkins, D.G. \& Houghton, S.D.1987. Age, correlation and palaeoecology of the St Erth Beds and the Coralline Crag of England. Mededelingen van de Werkgroep voor Tertiaire en Kwartaire Geologie 24, 147-156.

Jenkins, D.G., Curry, D., Funnell, B.M. \& Whittaker, J.E. 1988. Planktonic foraminifera from the Pliocene Coralline Crag of Suffolk, eastern England. Journal of Micropalaeontology 7, 1-10.

Johnson, A.L.A., Hickson, J.A., Swan, J., Brown, M.R., Heaton, T.H.E., Chenery, S. \& Balson, P.S. 2000. The Queen Scallop Aequipecten opercularis: a new source of information on late Cenozoic marine environments in Europe. In The Evolutionary Biology of the Bivalvia (eds E.M. Harper, J.D. Taylor \& J.A. Crame). pp. 425-439. Geological Society of London, Special Publications 177.

Jones, D.S., MacFadden, B.J., Webb, S.D., Mueller, P.A., Hodell, D.A. \& Cronin, T.M. 1991. Integrated geochronology of a classic Pliocene fossil site in Florida: linking marine and terrestrial biochronologies. Journal of Geology 99, 637-648.

Jones, D.S. \& Allmon, W.D. 1995. Records of upwelling, seasonality and growth in stable-isotope profiles of Pliocene mollusk shells from Florida. Lethaia 28, 61-74.

Knowles, T., Williams, M., Taylor, P.D. \& Okamura, B. 2006. Using bryozoans to infer patterns of global warming: a pilot study. International Bryozoology Association, Larwood Meeting, Trinity College, Dublin, 10 ${ }^{\text {th }}$ March, 2006. Abstracts volume, p. 9.

Krantz, D.E. 1990. Mollusk-isotope records of Plio-Pleistocene marine paleoclimate, U.S. Middle Atlantic Coastal Plain. Palaios 5, 317-335.

Lagaaij, R. 1963. Cupuladria canariensis (Busk) - portrait of a bryozoan. Palaeontology 6, 172-217.

Levitus, S. \& Boyer, T.P. 1994. World Ocean Atlas 1994, vol. 4, Temperature, NOAA Atlas NESDIS, vol. 4, 129 pp., NOAA, Silver Spring, Maryland.

Liesecki, L. \& Raymo, M.E. 2005. A Pliocene-Pleistocene stack of 57 globally distributed benthic $\delta^{18} \mathrm{O}$ records. Paleoceanography 20, PA1003, doi: 10.1029/2004PA001071. 17 pp. 
Louwye, S., Head, M.J. \& de Schepper, S. 2004. Dinoflagellate cyst stratigraphy and palaeoecology of the Pliocene in northern Belgium, southern North Sea Basin. Geological Magazine 141, 353-378.

Lunt, D.J., Valdes, P.J., Haywood, A.M. \& Rutt, I. 2008 Closure of the Panama Seaway during the Pliocene - Implications for Climate and Northern Hemisphere Glaciation. Climate Dynamics 30, 1-18. (doi:10.1007/s00382-007-0265-6).

Lyons, W.G. 1991. Post-Miocene species of Latirus Montfort, 1810 (Mollusca: Fasciolariidae) of Southern Florida, with a review of regional marine biostratigraphy. Bulletin of the Florida Museum of Natural History, Biological Sciences 35, 131-208.

Mathers, S.J. \& Zalasiewicz, J.A. 1988. The Red Crag and Norwich Crag formations of southern East Anglia. Proceedings of the Geologists’ Association 99, 261-278.

Mudelsee, M. \& Raymo, M.E. 2005. Slow dynamics of the Northern Hemisphere glaciation. Paleoceanography 20, PA-4022, doi:10.1029/2005PA001153.

O’Dea, A. \& Okamura, B. 1999. Influence of seasonal variation in temperature, salinity and food availability on module size and colony growth of the estuarine bryozoan Conopeum seurati. Marine Biology 135, 581-588.

O’Dea, A. \& Okamura, B. 2000. Intracolony variation in zooid size in cheilostome bryozoans as a new technique for investigating palaeoseasonality. Palaeogeography, Palaeoclimatology, Palaeoecology 162, 319-332.

O'Neil, J.R., Clayton, R.N., and Mayeda, T.K. 1969. Oxygen isotope fractionation in divalent metal carbonates. Journal of Chemical Physics 51, 5547-58

Okamura, B. \& Bishop, J.D.D. 1988. Zooid size in cheilostome bryozoans as an indicator of relative palaeotemperature. Palaeogeography, Palaeoclimatology, Palaeoecology 66, 145-152.

Quitmyer, I.R. \& Jones, D.S. 1997. The sclerochronology of hard clams, Mercenaria spp., from the southeastern U.S.A.: a method of elucidating the zooarchaeological records of seasonal resource procurement and seasonality in prehistoric middens. Journal of Archaeological Science 24, 825-840. 
Raffi, S., Stanley, S.M. \& Marasti, R. 1985. Biogeographic patterns and PlioPleistocene extinction of Bivalvia in the Mediterranean and southern North Sea. Paleobiology 11, 368-388.

Rohling, E. J. 2000. Paleosalinity: Confidence limits and future applications. Marine Geology 163, 1-11.

Rohling, E. J. \& Bigg, G.R, 1998. Paleosalinity and $\delta^{18} \mathrm{O}$ : a critical assessment, Journal of Geophysical Research 103, 1307-1318.

Roy, K., Jablonski, D., Valentine, J.W. \& Rosenberg, G. 1998. Marine latitudinal gradients: tests of causal hypotheses. Proceedings of the National Academy of Sciences of the United States of America 95, 3699-3702.

Shackleton, N.J., Crowhurst, S., Hagelberg, T., Pisias, N.G. \& Schneider, D.A. 1995. A new late Neogene time scale: Application to Leg 138 sites. Proceedings of the Ocean Drilling Program Scientific Results 138, 73-101.

Schmidt, G.A. 1998. Oxygen-18 variations in a global ocean model. Geophysical Research Letters 25, 1201-1204.

Schöne, B.R., Fiebig, J., Pfeiffer, M., Gless, R., Hickson, J., Johnson, A.L.A., Dreyer, W. \& Oschmann, W. 2005. Climate records from a bivalved Methuselah (Arctica islandica, Mollusca; Iceland). Palaeogeography, Palaeoclimatology, Palaeoecology 228, 130-148.

Swertz, O.C., Collin, F., Hofstraat, H.W. \& Althuis, B.A. 1999. Temperature, salinity, and fluorescence in southern North Sea: high resolution data sampled from a ferry. Environmental Management 23, 527-538.

Ward, L.W. \& Powars, D.S. 2004. Tertiary lithology and paleontology, Chesapeake Bay Region. In Geology of the National Capital Region - Field Trip Guidebook (eds S. Southworth \& W. Burton). pp. 264-297. U.S. Geological Survey Circular 1264.

Ward, L.W., Bailey, R.H. \& Carter, J.G. 1991. Pliocene and Early Pleistocene stratigraphy, depositional history, and molluscan paleobiogeography of the coastal plain. In The Geology of the Carolinas: Carolina Geological Society fiftieth anniversary volume (eds J.W. Jr. Horton \& V.A. Zullo). pp. 274 -289. Knoxville: University of Tennessee Press. 
Wilkinson, I.P. 1980. Coralline Crag Ostracoda and their environmental and stratigraphical significance. Proceedings of the Geologists' Association 91, 291306.

Witbaard, R. \& Bergman, M.J.N. 2003. The distribution and population structure of the bivalve Arctica islandica L. in the North Sea: what possible factors are involved? Journal of Sea Research 50, 11-25.

Wood, A.M., Whatley, R.C., Cronin, T. \& Holtz, T. 1993. Pliocene palaeotemperature reconstruction for the southern North Sea based on Ostracoda. Quaternary Science Reviews 12, 747-767.

Zachos, J.C., Stott, L.D. \& Lohmann, K.C. 1994. Evolution of early Cenozoic marine temperatures. Paleoceanography 9, 353-387.

Zachos, J., Pagani, M., Sloan, L., Thomas, E \& Billups, K. 2001. Trends, rhythms, and aberrations in global climate $65 \mathrm{Ma}$ to present. Science 292, 686-693.

Figure 1. Geographical location of the Coralline Crag Formation, eastern England ('North Sea'), the Yorktown Formation of Virginia and lateral equivalents in the Carolinas, and the Tamiami Formation of Sarasota, Florida. DSDP sites 548 and 552 are also plotted (see text). Base map, courtesy of Harry Dowsett, shows modern surface ocean circulation (arrows).

Figure 2. Pliocene stratigraphy of rock successions bordering the North Atlantic. Coralline Crag Formation, comprising Ramsholt (RS), Aldeburgh (AL) and Sudbourne (SB) members. Yorktown Formation of Virginia - Carolinas comprising Sunken Meadow (SM), Rushmere (RM), Morgart's Beach (MB) and Moore House $(\mathrm{MH})$ members. The uppermost Moore House Member $(\mathrm{MH})$ is restricted to southeastern Virginia (Ward et al. 1991). Tamiami Formation, Florida. 'Unit 11' in the lower Tamiami Formation is considered of equivalent age to the Sunken Meadow Member (SM) of the Yorktown Formation (Jones et al. 1991). The overlying Lower Pinecrest Beds (units 10-5) are equivalent to the Morgart's Beach/Rushmere/Moore House members of the Yorktown Formation (Cronin \& Dowsett 1996). For an exhaustive account of Tamiami Formation and 'Pinecrest Beds' nomenclature, including 'Unit 11', see Lyons (1991). The 'mid Pliocene warm period' is also plotted 
as is a selected segment of the isotope curve of Lisiecki \& Raymo (2005). Plotted in the column for series and stages are absolute dates based on Gradstein et al. (2004) and some selected cool phases (glacials) of the Pliocene (Gi20, Gi4, MG4, MG2, M2, Km2, G20; see Dowsett et al. 1999; Lisiecki \& Raymo 2005).

Figure 3. (a) The queen scallop Aequipecten opercularis, used to establish sea temperatures in the Coralline Crag Formation of Suffolk, England; and (b) the bryozoan Microporella aff. ciliata, a potental source of MART data, from the Tamiami Formation, Sarasota, Florida.

Figure 4. Climate model prediction showing change in annual mean ocean top level $(0-5 \mathrm{~m})$ temperatures between the Early Pliocene and pre-industrial (top), and the 'mid-Pliocene warm period' and the pre-industrial (bottom), for the North Atlantic region. Red dots mark, from north to south, Florida, Carolinas, Virginia, and southern North Sea (see also Fig. 1). Warmer conditions are demonstrated off the coast of the Carolinas/Virginia for the 'mid-Pliocene', which are supported by fossil data from these areas (see Tables 1, 2).

Table 1. Oceanographic data for sites in eastern England (Suffolk), Virginia, the Carolinas, and Florida. Present sea surface temperatures for the east coast of the USA are from http://www.nodc.noaa.gov/dsdt/cwtg/satl.html (downloaded November 2007; these sea temperatures are based on historical data collected from the given locations, Cape Charles, Cape Hatteras and Miami Beach): sea temperature data for the southern North Sea are from Swertz et al. (1999). Oxygen isotope data from molluscs, seawater $\delta^{18} \mathrm{O}$ estimates and temperature calculations are based on data in Krantz (1990) for Virginia, Jones \& Allmon (1995) for Florida, and Johnson et al. (2000) for eastern England. Note that for temperature calculations from the bivalves there is a slight possibility that the lowest and highest temperatures might have been missed by less-than-100\% sampling. However, while summer maxima might have been a little higher, winter minima might equally have been a little lower. This pertains to the data of Table 2 also. The maximum estimated range of Pliocene sea temperature variation is based on records from foraminifera, ostracods and molluscs at the various sites. Estimates of Pliocene temperature from ostracods are singled out, 
and are based on Wilkinson (1980) and Wood et al. (1993) for Suffolk, Hazel (1971) for Virginia, Cronin \& Dowsett (1990) for Carolina, and Cronin \& Dowsett (1996) for Florida. The table shows the marked change in seasonality compared to the present day for the east coast of the USA north of Cape Hatteras, with much warmer winter temperatures typifying the Pliocene.

Table 2. Recalibrated Pliocene sea temperature estimates using published data for bivalves from the Pliocene of eastern England (Johnson et al. 2000), Virginia (Krantz 1990) and Florida (Jones \& Allmon 1995). Temperatures for calcitic bivalves are calculated using the equation of O'Neil et al. $\left(1969 ;\left[\mathrm{T}^{\circ} \mathrm{C}=16.9-4.38\left(\delta^{18} \mathrm{O}_{\mathrm{c}}-\delta^{18} \mathrm{O}_{\mathrm{w}}\right)+\right.\right.$ $\left.\left.0.10\left(\delta^{18} \mathrm{O}_{\mathrm{c}}-\delta^{18} \mathrm{O}_{\mathrm{w}}\right)^{2}\right]\right)$ and those of aragonite bivalves utilise the equation of Grossman $\& \mathrm{Ku}(1986)$ in the form used by Schöne et al. $\left(2005 ; \mathrm{T}^{\circ} \mathrm{C}=20.6-4.34\left[\delta^{18} \mathrm{O}_{\mathrm{c}}-\left(\delta^{18} \mathrm{O}_{\mathrm{w}^{-}}\right.\right.\right.$ $0.2 \%$ )]). Diagnostic predictions of Pliocene seawater $\delta^{18} \mathrm{O}$ values are derived from fully coupled OAGCM simulations for the Early and 'mid' Pliocene (see text). Sea temperatures for Virginia are somewhat warmer than calculated by Krantz (1990), whilst those of eastern England and Florida are similar to previously published calculations. Carré et al. (2005) have suggested that the Grossman \& Ku equation does not describe the oxygen fractionation of all bivalves. In the column for the modern seasonal range of sea temperatures, the values for Cape Charles in Virginia are from http://www.nodc.noaa.gov/dsdt/cwtg/satl.html (downloaded November 2007), those for Florida are from Cronin \& Dowsett $(1990,1996)$, and for the North Sea are from Swertz et al. (1999). In the right hand column, calculations for winter and summer difference in sea temperature between Pliocene and modern are based on the temperatures shown in bold in columns 8 and 9 . 


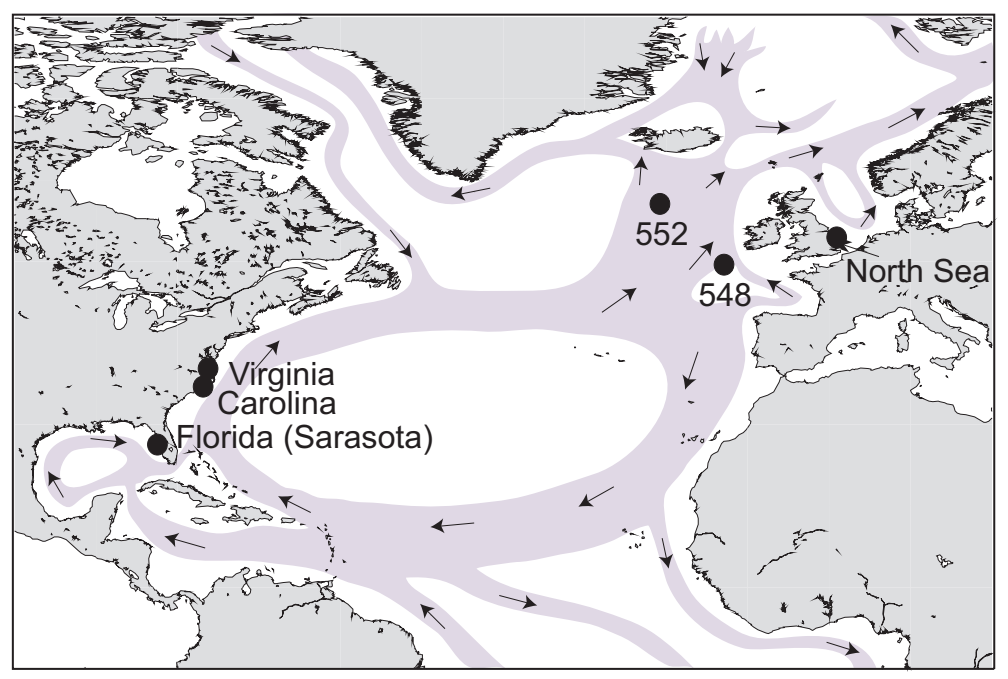




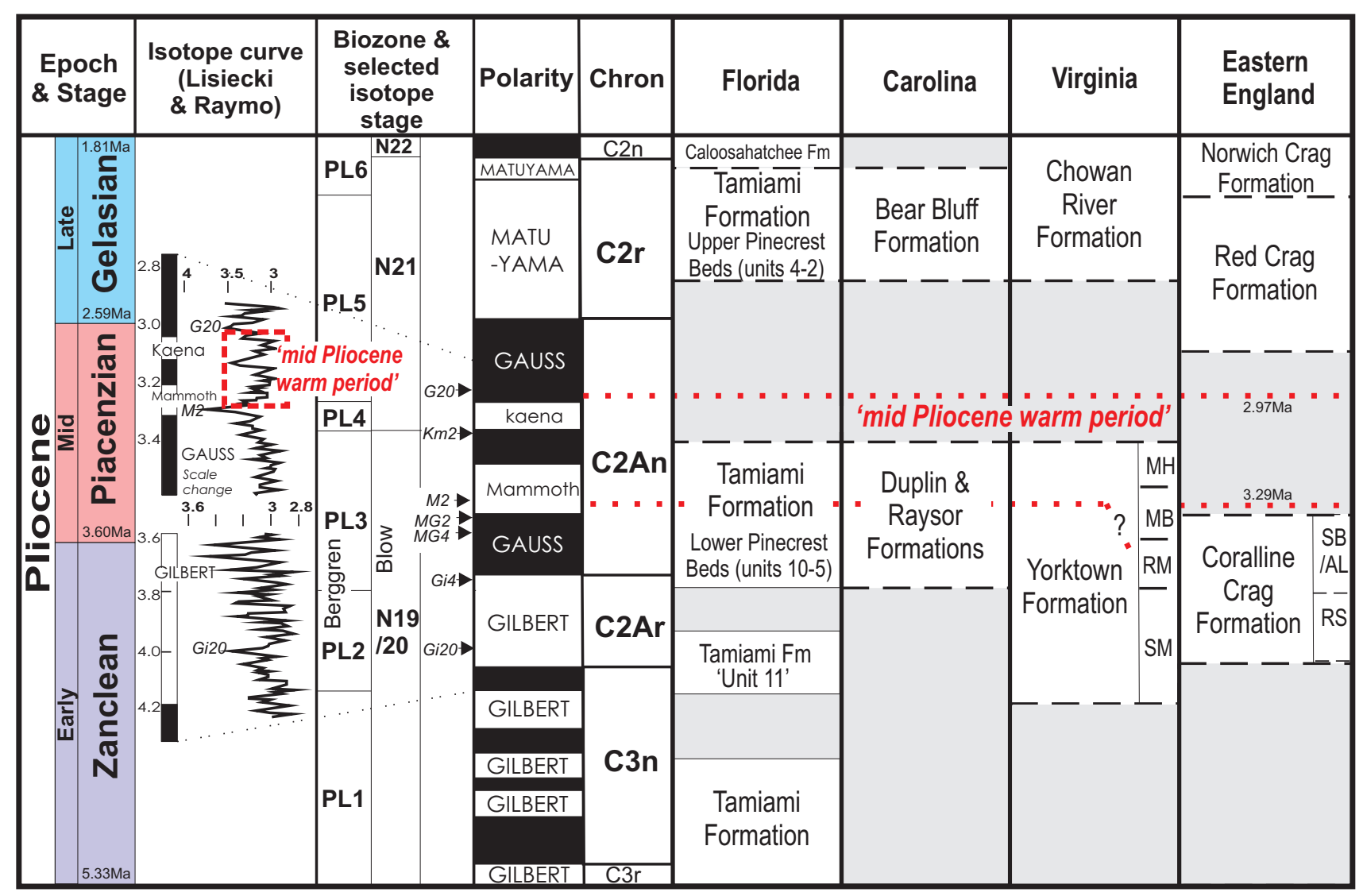




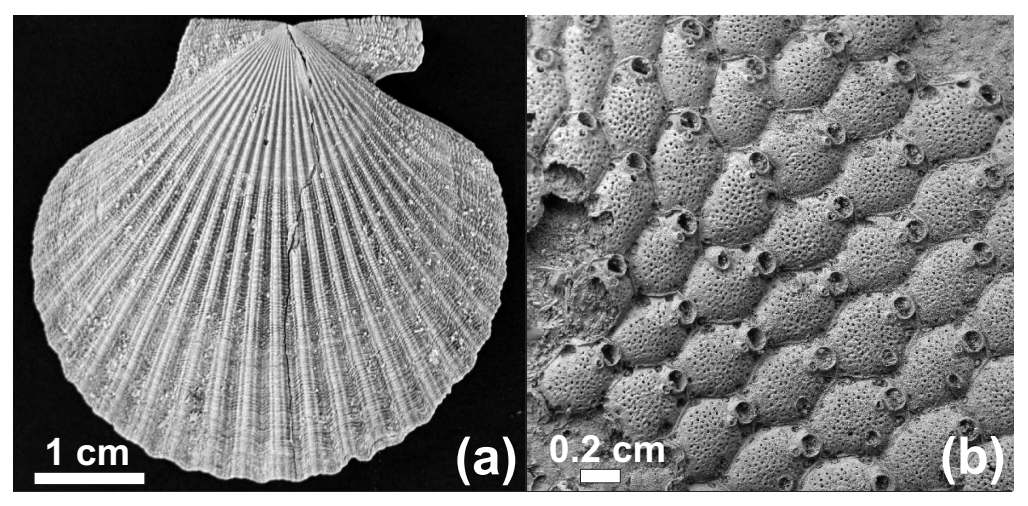




\begin{tabular}{|c|c|c|c|c|c|c|c|c|}
\hline $\begin{array}{l}\text { Modern } \\
\text { latitude/ } \\
\text { locality }\end{array}$ & $\begin{array}{l}\text { Modern } \\
\text { SST range } \\
\left({ }^{\circ} \mathrm{C}\right)\end{array}$ & $\begin{array}{l}\text { Modern } \\
\text { Seasonal } \\
\text { range }\left({ }^{\circ} \mathrm{C}\right)\end{array}$ & $\begin{array}{c}\text { Maximum } \\
\text { seasonal range } \\
\text { of Pliocene } \\
\text { temperature } \\
\text { (forams, } \\
\text { ostracods \& } \\
\left.\text { molluscs) ( }{ }^{\circ} \mathrm{C}\right) \\
\end{array}$ & $\begin{array}{l}\text { Ostracod } \\
\text { Pliocene } \\
\text { temperature } \\
\text { range }\left({ }^{\circ} \mathrm{C}\right)\end{array}$ & $\begin{array}{c}\text { Estimated } \\
\text { Pliocene } \\
\text { seasonal range } \\
\left({ }^{\circ} \mathrm{C}\right)\end{array}$ & $\begin{array}{c}\text { Seawater } \delta^{18} O \\
\text { estimate used in } \\
\text { temperature } \\
\text { calculations }\end{array}$ & $\begin{array}{c}\text { Maximum } \\
\text { seasonal range } \\
\text { of Pliocene sea } \\
\text { temperatures } \\
\text { from molluscs } \\
\left({ }^{\circ} \mathrm{C}\right)\end{array}$ & $\begin{array}{l}\text { Selected Pliocene sea } \\
\text { temperatures from molluscs } \\
\left({ }^{\circ} \mathrm{C}\right)\end{array}$ \\
\hline $\begin{array}{l}\text { Suffolk } \\
52 \text { deg } 16 \\
\min N\end{array}$ & $\begin{array}{c}4-17 \\
\text { (southern N } \\
\text { Sea) }\end{array}$ & 13 & $\begin{array}{l}\text { 5.5-24 (Coralline } \\
\text { Crag, all } \\
\text { lithological } \\
\text { members) }\end{array}$ & 10 to 24 & $\begin{array}{c}\text { 6.6 MART (range 4.6 } \\
8.9 \text { ) bryozoans }\end{array}$ & $\begin{array}{l}\text { calculations where } \\
\text { no ice volume } \\
\text { correction was } \\
\text { applied }\end{array}$ & 6.5 to 16.2 & $\begin{array}{c}\text { 6.5-16.2 Aequipecten opercularis } \\
\text { (2 specimens, with no ice } \\
\text { correction) }\end{array}$ \\
\hline $\begin{array}{l}\text { Virginia } \\
37 \operatorname{deg} 10 \\
\min N\end{array}$ & $\begin{array}{l}4.4-25.5 \\
\text { (Cape } \\
\text { Charles) }\end{array}$ & 21 & $\begin{array}{l}\text { 8.2-23.9 }(\mathrm{MH}, \\
\text { Yorktown) }\end{array}$ & 12.5 to 22.5 & \begin{tabular}{|c|}
11 ( $\delta 180$ of -1.4 to \\
+1.3 per mil in $C$. \\
eboreus) with \\
minimum ice volume \\
correction
\end{tabular} & -0.2 to -0.5 per mil & 8.2 to 23.9 & $\begin{array}{c}\text { 8.9-23.9 Chesapecten madisonius } \\
\text { (2 specimens) \& 10.1-21.1 } \\
\text { Carolinapecten eboreus }\end{array}$ \\
\hline $\begin{array}{l}\text { Virginia } \\
37 \operatorname{deg} 10 \\
\min N\end{array}$ & $\begin{array}{l}4.4-25.5 \\
\text { (Cape } \\
\text { Charles) }\end{array}$ & 21 & $\begin{array}{l}\text { 6.8-25 (RM, MB, } \\
\text { Yorktown) }\end{array}$ & 12.5 to 25 & $\begin{array}{c}14.3 \text { ( } \delta 180 \text { of }-1.9 \text { to } \\
+1.6 \text { per mil in } C . \\
\text { madisonius) with } \\
\text { minimum ice volume } \\
\text { correction }\end{array}$ & -0.3 to -0.6 per mil & 6.8 to 22.9 & $\begin{array}{c}\text { 8.6-22.9 Chesapecten madisonius } \\
\text { \& 7.9-13.5 Carolinapecten } \\
\text { eboreus (both with minimum ice } \\
\text { volume correction) }\end{array}$ \\
\hline $\begin{array}{l}\text { Virginia } \\
37 \operatorname{deg} 10 \\
\min N\end{array}$ & $\begin{array}{l}4.4-25.5 \\
\text { (Cape } \\
\text { Charles) }\end{array}$ & 21 & $\begin{array}{l}7.1-20(\mathrm{SM}, \\
\text { Yorktown) }\end{array}$ & 10 to 20 & $\begin{array}{c}9.5 \text { ( } \delta 180 \text { of }-0.8 \text { to } \\
+1.6 \text { per mil in } C . \\
\text { jeffersonius shell) with } \\
\text { minimum ice volume } \\
\quad \text { correction }\end{array}$ & -0.3 to -0.4 per mil & 7.1 to 19.8 & $\begin{array}{c}\text { 7.5-19.8 Chesapecten jeffersonius } \\
\text { (2 specimens, with the minimum } \\
\text { ice volume correction) }\end{array}$ \\
\hline $\begin{array}{l}\text { Carolina } \\
35 \operatorname{deg} 13 \\
\min N\end{array}$ & $\begin{array}{l}10-26.6 \\
\text { (Cape } \\
\text { Hatteras) }\end{array}$ & 16 & 18-26 (Duplin) & 18 to 26 & sub-tropical & no data & no data & no data \\
\hline $\begin{array}{l}\text { Florida } \\
25 \operatorname{deg} 47 \\
\min N\end{array}$ & $\begin{array}{l}23-30 \\
\text { (Miami } \\
\text { Beach) }\end{array}$ & 7 & $\begin{array}{c}6.9-25.7 \text { (Lower } \\
\text { Pinecrest Beds unit } \\
6 / 7 \text { ) }\end{array}$ & 18 to 26 & $\begin{array}{c}7.8 \text { to } 9.2(M . \\
\text { campechiensis }) \text { or } \\
9.3(\text { Turritella }) \text { both } \\
\text { with no ice volume } \\
\text { correction }\end{array}$ & $\begin{array}{c}-0.3 \text { to }-0.6 \text { per mil, } \\
\text { and some with no ice } \\
\text { volume correction }\end{array}$ & 6.9 to 25.7 & $\begin{array}{c}\text { 14.2-24.3 Mercenaria campechiensis } \\
\text { (2 specimens) \& } 16.4-25.7 \text { Turritella } \\
\text { apicalis (both ranges based on } \\
\text { calculations with no ice volume } \\
\text { correction) }\end{array}$ \\
\hline
\end{tabular}




\begin{tabular}{|c|c|c|c|c|c|c|c|c|c|c|}
\hline $\begin{array}{l}\text { Fossil } \\
\text { locality }\end{array}$ & Mollusc species & $\begin{array}{c}\text { Mollusc } \\
\delta^{18} O\end{array}$ & $\begin{array}{c}\text { Fossil } \\
\text { identifier } \\
\text { (from } \\
\text { original } \\
\text { papers) }\end{array}$ & $\begin{array}{c}\text { Latitude used } \\
\text { in seawater } \\
\text { calculation }\end{array}$ & \begin{tabular}{|c|} 
Early \\
Pliocene \\
model \\
predicted \\
seawater \\
$\delta^{18} O$ \\
\end{tabular} & \begin{tabular}{|c|} 
'mid \\
Pliocene' \\
model \\
predicted \\
seawater \\
$\delta^{18} O$ \\
\end{tabular} & \begin{tabular}{|c|} 
Revised \\
mollusc \\
temperatures \\
for 'mid \\
Pliocene' \\
scenario $\left({ }^{\circ} \mathrm{C}\right)$ \\
\end{tabular} & $\begin{array}{c}\text { Revised } \\
\text { mollusc } \\
\text { temperatures } \\
\text { for Early } \\
\text { Pliocene } \\
\text { scenario }\left({ }^{\circ} \mathrm{C}\right) \\
\end{array}$ & $\begin{array}{c}\text { Modern } \\
\text { temperature } \\
\text { range }\left({ }^{\circ} \mathrm{C}\right)\end{array}$ & $\begin{array}{c}\text { Winter(w) } \\
\text { summer(s) } \\
\text { difference } \\
\text { Pliocene- } \\
\text { modern }\left({ }^{\circ} \mathrm{C}\right)\end{array}$ \\
\hline $\begin{array}{l}\text { Virginia } \\
\text { (SM) }\end{array}$ & $\begin{array}{l}\text { C. jeffersonius } \\
\text { (calcite) }\end{array}$ & 1.5 to -1.2 & KING-CJ & $37.1 \mathrm{~N} 72.5 \mathrm{~W}$ & 0.7 & 1.1 & 14.1 to 26.3 & 12.4 to 24.4 & 4.4 to 25.5 & $\begin{array}{c}8(w) \\
\&-1.1(s)\end{array}$ \\
\hline $\begin{array}{l}\text { Virginia } \\
\text { (RM/MB) }\end{array}$ & $\begin{array}{l}\text { C. jeffersonius } \\
\text { (calcite) }\end{array}$ & 1.6 to -1.9 & BB-CM & $37.1 \mathrm{~N} 72.5 \mathrm{~W}$ & 0.7 & 1.1 & 13.6 to 29.7 & 12 to 27.7 & 4.4 to 25.5 & $\begin{array}{c}7.2(w) \\
\& 4.2(s)\end{array}$ \\
\hline $\begin{array}{l}\text { Virginia } \\
(\mathrm{MH})\end{array}$ & $\begin{array}{l}\text { C. jeffersonius } \\
\text { (calcite) }\end{array}$ & 1.3 to -2 & YAD-CM2 & $37.1 \mathrm{~N} 72.5 \mathrm{~W}$ & 0.7 & 1.1 & 14.9 to 30.1 & 13.2 to 28.2 & 4.4 to 25.5 & $\begin{array}{c}10.5(\mathrm{~s}) \\
\& 4.6(\mathrm{w})\end{array}$ \\
\hline $\begin{array}{l}\text { Florida } \\
\text { (unit6/7) }\end{array}$ & $\begin{array}{l}\text { M. campechiensis } \\
\text { (aragonite) }\end{array}$ & 1.8 to -0.25 & MC130 & $27.4 \mathrm{~N} 82.5 \mathrm{~W}$ & 0.9 & 1.02 & 16.3 to 25.2 & 15.8 to 24.7 & $16-27$ & $\begin{array}{c}0.3(w) \\
\&-1.8(s)\end{array}$ \\
\hline $\begin{array}{l}\text { Florida } \\
\text { (unit6/7) }\end{array}$ & $\begin{array}{l}\text { M. campechiensis } \\
\text { (aragonite) }\end{array}$ & 1.7 to -0.75 & MC121 & $27.4 \mathrm{~N} 82.5 \mathrm{~W}$ & 0.9 & 1.02 & 16.8 to 27.4 & 16.3 to 26.9 & $16-27$ & $\begin{array}{c}0.8(w) \\
\& 0.4(s)\end{array}$ \\
\hline $\begin{array}{l}\text { Suffolk } \\
\text { (CC) }\end{array}$ & $\begin{array}{l}\text { A. opercularis } \\
\text { (calcite) }\end{array}$ & 2.4 to 0.7 & UD 52796 & $53.5 \mathrm{~N} 2 \mathrm{E}$ & 0.09 & 0.14 & 6.5 to 13.4 & 6.3 to 13.2 & 4 to 17 & $\begin{array}{c}2.3(w) \\
\&-3.8(s)\end{array}$ \\
\hline $\begin{array}{l}\text { Suffolk } \\
\text { (CC) }\end{array}$ & $\begin{array}{l}\text { A. opercularis } \\
\text { (calcite) }\end{array}$ & 1.7 to -0.10 & UD 52797 & $53.5 \mathrm{~N} 2 \mathrm{E}$ & 0.09 & 0.14 & 9.1 to 16.6 & 9.1 to 16.6 & 4 to 17 & $\begin{array}{c}5.1(w) \\
\&-0.4(s)\end{array}$ \\
\hline
\end{tabular}



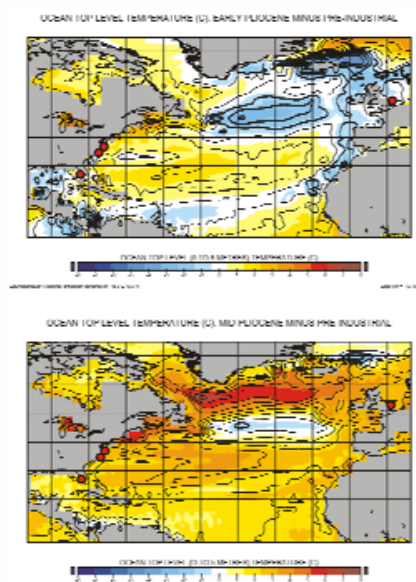